ISSN No. 0974-035X

An indexed refereed \& peer-reviewed journal of higher education

Towards Excellence

UGC-HUMAN RESOURCE DEVELOPMENT CENTRE

Gujarat University, Ahmedabad-380009, Gujarat, India

\title{
PRIVATISATION OF INDIAN RAILWAYS: PROSPECTS AND CONSEQUENCES
}

\author{
Dr. T. Rajasekar \\ Dr. Safeer Pasha M
}

\section{Abstract}

The baseline of the research work tries to explore the effect of privatisation on Indian railways. Adoption of any policy may have both positive and negative effect. Considering this perspective, the present study explores the prospective measures as well as consequence effect while adopting privatization policy in the Railway sector. The study found that efficiency, quality of services, lesser accidents, fewer political intervene, shareholders value and technological innovation as the prospective measures while adopting privatisation concepts. The study also found that limited coverage, higher fares, accountability and impact on economy as the consequences measures while adopting the privatisation policy in Indian Railways. Therefore, adopting the privatisation policy in the railway sector consideration must be given to the above said factors for future development.

Key words: Privatization, Indian railways, Prospects, Consequences

\section{Introduction}

Privatisation leads to transfer the ownership from public to private, in other word selling the government owned assets into private owned. It was proved that private sector can run their business concern more efficiently and effectively because of their target oriented and focuses of their business. It is also believed that private sector can exploit their monopoly power and ignore welfare of the peoples. Privatisation can vigorously achieved in various 
Towards Excellence: An Indexed, Refereed \& Peer Reviewed Journal of Higher Education / Dr. T. Rajasekar \& Dr. Safeer Pasha/ Page 49-59

concerns like power, telecom, banks and so on by selling their shares to the private sectors. In spite of having discussion on the subject over the last 20 years regarding the privatisation of Indian railways. The government also partially started privatisation into the railways by giving outsourcing services like housekeeping, catering and maintaining the stations in the selected areas. However, these participation of private sector in railways in national wide debate as this privatisation would indeed be the right step. In this scenario railways in India moving towards privatisation of some of the stations by public private projects. Under this project, selected stations may give to private concern for modernization. The modernization includes building malls in the station, cinema halls, hotels as well as super speciality hospitals in the railway premises. This business model ensures to the development work such as rebuilding premises in the railway stations for next 15 years without any investment from government. In return the concerned private sector may be granted the leasing opportunity for the developed commercial properties another 50 years. These leasing opportunity includes platform maintenance, parking charges, food counters at stations, waiting rooms etc. The revamping of the railway stations is planned to various stages. In preliminary phase, the accountability had given to Indian Railway Station Development Corporation (IRSDC) for revamping the stations and its facilities. In this connection the revamping of work of Habibgani Railway Station have already started by Bansal Group for which they have obtained 400 crores as loan in respect to provide the facilities like electricity, platform charges and maintenance, parking facilities, food counters, waiting rooms etc. The next phase the following 23 railway stations have found which will be auctioned such as "Kanpur Central, Allahabad, Lokmanya Tilak, Pune, Thane, Visakhapatnam, Howrah, Kamakhya, Faridabad, Jammu Tawi, Udaipur City, Secundrabad, Vijayawada, Ranchi, Chennai Central, Kozhikode, Yesvantpur, Bangalore Cantt, Bhopal, Mumbai Central, Bandra Terminus, Borivali and Indore stations". This revamping works will be carried out under foreign direct investment, some of 
Towards Excellence: An Indexed, Refereed \& Peer Reviewed Journal of Higher Education / Dr. T. Rajasekar \& Dr. Safeer Pasha/ Page 49-59

the international companies like "Malaysia's state owned Construction Industry Development Board (CIDB)", many Korean and Japanese companies given their expression of interest. During 2014 the country allowed 100\% FDI in railway infrastructure development, through this some of the foreign companies already established two rail loco factories in Bihar with the investment of Rs.3500 crores.

Indian railways carried 2.3 crore people and 3 million tons of goods every day. Most of the Indian population rely on public transport system instead of private transports. Railways are the most feasible transport for all the sections of the society, which also connect geographically different population in each day. Indian Railways connecting all the parts of the country especially connect with remote area which runs 12617 trains to carry both passengers as well as freight. The concept of privatisation may affect connectivity of these remote areas due to economic position. Normally private sector prefers to run their services from profitable route nor the non-profitable routes. However, all these activities of privatisation is a nationwide debate whether privatisation would indeed the right step. The accuracy can be judged by studying the prospects and consequences of privatisation in Indian railways.

India's first private operated train Tejas Express successfully launched on $4^{\text {th }}$ October 2019 from New Delhi to Lucknow in charged by Indian Railways Catering and Tourism Corporation Limited, which covers $512 \mathrm{~km}$ in 6 hours and 30 minutes. Subsequently the government of India has decided to give approval for 150 more private operated trains and routes which was cleared by public private partnership appraisal committee (PPPAC) was consider as new milestone for Indian Railways. The following routes planned to give private operated trains in India; "Mumbai-Kolkata, Mumbai-Chennai, Mumbai-Guwahati, New DelhiMumbai, Thiruvananthapuram-Guwahati, New Delhi-Kolkata, New Delhi-Bengaluru, NewDelhi-Chennai, Kolkata-Chennai, Chennai-Jodhpur, Mumbai-Varanasi, Mumbai-Pune, Mumbai-Lucknow, Mumbai-Nagpur, Nagpur-Pune, Secunderabad-Visakhapatnam, Patna- 
Towards Excellence: An Indexed, Refereed \& Peer Reviewed Journal of Higher Education / Dr. T. Rajasekar \& Dr. Safeer Pasha/ Page 49-59

Bengaluru, Pune-Patna, Chennai-Coimbatore, Chennai-Secunderabad, Surat-Varanasi and Bhubaneswar-Kolkata". Apart from these, some of the other routes connecting non-metro cities such as "Allahabad, Amritsar, Chandigarh, Katra, Gorakhpur, Chhapra and Bhagalpur, Gorakhpur-Lucknow, Kota-Jaipur, Chandigarh-Lucknow, Visakhapatnma-Tirupati and Nagpur-Pune" have also under the consideration to give private operated trains. Generally, there will be 35 routes connecting to New Delhi, 26 routes connecting to Mumbai, 12 routes connecting to Kolkata, 11 routes connecting with Chennai and 8 routes connecting with Bengaluru under the privatisation.

Table - 1. List of Private operated trains in charged with IRCTC

\begin{tabular}{|l|l|l|ll|}
\hline S. No & Private operated Tejas Express & Distance & Duration \\
\hline 1. & $\begin{array}{l}\text { Kashi Mahakal Express, Varanasi to } \\
\text { Indore (via Lucknow and Allahabad) }\end{array}$ & $1131 \mathrm{~km}$ & 19 hours \\
\hline 2. & New Delhi - Lucknow - New Delhi & $512 \mathrm{~km}$ & $\begin{array}{l}6 \text { hours } \\
\text { minutes }\end{array}$ \\
\hline 3. & Mumbai - Ahmedabad - Mumbai & $491 \mathrm{~km}$ & 6 hours \\
\hline
\end{tabular}

The above table illustrates the present list of private operated trains in charged with IRCTC. The salient features of these trains as follows;

- Complementary on board information and entertainment services to the passengers, such as news, sports, media and television etc.,

- Hygiene foods and brews will be served to the passengers

- Services inside the train will be done through trolleys similar to airlines also provide the RO water as well as packaged water bottle for all the passengers.

- All passengers avail insurance of up to Rs. 25 lakhs free of cost by IRCTC and additional insurance for theft / robbery covers Rs. 1 lakh of the passengers.

- Repayment of full amount on confirmed or waiting list tickets in case the train will be called off.

- The additional facilities like tatkal or premium tatkal will not available in these trains. 
Towards Excellence: An Indexed, Refereed \& Peer Reviewed Journal of Higher Education / Dr. T.

Rajasekar \& Dr. Safeer Pasha/ Page 49-59

Table - 2. Road map and Action plan of privatisation of Indian Railways

\begin{tabular}{|c|c|c|}
\hline Road map & Action plan & Partners \\
\hline $\begin{array}{l}\text { - } 150 \text { private trains } \\
\text { planned to run across } \\
\text { the country } \\
\text { - Around } 2400 \text { coaches to } \\
\text { be used in private } \\
\text { operated trains } \\
\text { - Expecting around } 16000 \\
\text { crores as investment } \\
\text { from private operators } \\
\text { - The operations would } \\
\text { like to complete by } \\
2023-24\end{array}$ & $\begin{array}{l}\text { - } \text { IRCTC finalising } \\
\text { qualifications and proposals } \\
\text { - } \quad \text { Bids may be finalized based } \\
\text { on timing and routes } \\
\text { - Trains may like to operate at } \\
160 \text { kmph on selected } \\
\text { routes } \\
\text { - Operators can fix the fares } \\
\text { in charged by IRCTC } \\
\text { - Hire certified loco pilots by } \\
\text { railways, which may also } \\
\text { offers value added services } \\
\text { like luggage pick up and } \\
\text { drops }\end{array}$ & $\begin{array}{ll}\text { - } & \text { Deutsche } \\
& \text { Bahn AG } \\
& \text { (Germany) } \\
\text { - } & \text { SNCF } \\
& \text { (France) } \\
\text { - } & \text { MTR } \\
& \text { (Singapore) } \\
\text { - } & \text { Virgin Trains } \\
& \text { (UK) } \\
\text { - } & \text { First (UK) } \\
\text { - } & \text { Renfe (Spain) }\end{array}$ \\
\hline
\end{tabular}

Rest of the paper organizes as follows; section 2 deals with previous studies have concentrated with privatisation policy in railway sector, section 3 gives the materials and methods of research work adopted in the present study and section 4 provides the discussion section in respect with prospects and consequences of adopting privatisation in Indian railways, finally section 5 delivers the concluding remarks of the study.

\section{Earlier studies}

Hilmola, O. P. et al (2007) studied the deregulation of railroads and future development in Europe based on the quantitative materials which contains three different countries like USA, UK and Sweden. This study found that deregulation of policies has brought positive performance in long term as well as short term perspective in all the regions except UK which gives negative effects in short term manner. Kikeri, S \& John, N. (2004) empirically investigated the benefits of the privatization in sector wise. The study found that competitive sectors privatization has been a resounding success in improving firm performance. The study concludes that growing concerns of privatisation should be reversed in periodically based on its needs. Gupta, N. (2002) studied the effect of partial privatization and firm's performance. The study stated that most of the privatization programs begin with a partial 
Towards Excellence: An Indexed, Refereed \& Peer Reviewed Journal of Higher Education / Dr. T. Rajasekar \& Dr. Safeer Pasha/ Page 49-59

manner so that it will not affect the firm and also found that partial privatization has a positive and highly significant impact on firm's sales, profit and productivity. Ponti, M \& Stefano, E (2002). Studied the effect of liberalization of European railway sector from 'public choice perspective'. Through the study it found that liberalization can minimize the discretionary components within the decision-making and improve in cost-benefit techniques. It also increasing the efficiency goals of the organization. Finally, it concludes that liberalization helps to increase transparency, better social effectiveness both for environmental and for redistributive goals. White, P \& John, B. (2002) studied the experience of national railway privatisation, and vertical separation of metro systems in European countries. Through this study the authors found that privatisation must be ensure the responsibility of the event of safety issues and delays affecting final users and also they found that is it private or public sector must have appropriate controls in place. This can be eliminated the problems faced by rail track in the light of the Hatfield crash.

Based on the previous studies it is understood that most of the studies have measured the relationship between privatization and firm's value in and around the globe. However, the studies are lack to explore the prospects and consequences of privatization in specific. Hence the present study tries to explore the prospects and consequences of privatization of Indian railways.

\section{Methodology}

The main aim of the study tries to explore the effect of privatisation on Indian railways. Adoption of any policy may have both positive and negative effect. Considering this point, the study explores the prospective measures as well as consequence effect while adopting privatization in the Railway sector. Exploring those prospective and consequences measures, the present study adopts observation as well as discussion method to the person who is 
Towards Excellence: An Indexed, Refereed \& Peer Reviewed Journal of Higher Education / Dr. T.

Rajasekar \& Dr. Safeer Pasha/ Page 49-59

directly or indirectly related to the railway sectors such as passengers, railway employees in cadre wise, retired employees and vendors. Based on these efforts the study could come with prospects and consequences of adopting privatisation in Indian Railways as follows;

\section{Discussion}

In the below points it can be discussed the prospects and consequences for privatization of Indian Railways.

\section{Prospects:}

\section{Efficiency:}

A strong argument in favour of privatization is that will improve the usage of infrastructure which will turn into the better amenities for the passengers. As opposed to mismanagement in form of dirty stations, reckless behaviour of railway employees, stinking washrooms, pick-pocketing, sanitation problems, food poisoning and insecurity around stations is expected that privatization will ensure better amenities. Because for privatization is that private companies have a profit incentive to cut costs and be more efficient.

\section{Quality of Service:}

Most of the passenger's complaints regarding the Indian railways is that less quality of services match with the charges paid up them. Those who supports privatisation feel that this problem may be rectified by the private sector and provide betterment in the quality of service is concern.

\section{Less accidents:}

Train related accidents may happen because of physical as well as mental strain among the authorities and supporters feels that private sector may have better maintenance, good relationship among the employees may reduce the accidents which resulting safe travel and higher monetary saving in long term manner. 


\section{Rajasekar \& Dr. Safeer Pasha/ Page 49-59}

\section{Less political intervene:}

Government sector make poor economic employees because they are motivated by political pressures rather than the economic and business perspective. Which may lead excess employees in the organization resulted in poor efficiency. This may be rectified in the private sectors because they may appoint needed person with less political intervene.

\section{Shareholders value:}

The argument in favour of privatisation is shareholder's worth, because private sector always has the pressure from the shareholders the firm to perform efficiently this is not in the government sector which may lead to inefficient.

\section{Technological innovation:}

Another strong opinion in favour of privatisation is technological innovation. Most of the stakeholders believed that privation in Railway sector brings modern technology and capacity building in terms of coaches, housekeeping, welfare activities etc.,

\section{Consequences:}

\section{Limited coverage:}

One of the main advantage of Indian railways in government owned, because it provides services to the entire national irrespective of the profit. This may not possible from the private sector because it may have connected with familiar routes which can earn more profit. The lesser profit routes may be disconnected by the private sector operations.

\section{Higher fares:}

The main aim of the private enterprises is profit oriented, it is quiet natural that private sector may hike the fares and rendering services this may be the easiest way to increase the profit. They may not consider the lower class people rather consider their profit for undertaking. 


\section{Accountability:}

Private sector enterprises dealings are unpredictable and they do not share their secrets with governments or the world. In such situation it is very difficult to pin the accountability for every entry therefore discrepancy arises.

\section{Impact on Economy:}

Indian economy is backboned by agricultural as well as industrial sectors. Most of the farmers and manufacturers are using railway services for their connectivity and logistics activities. Railway also offering low fares for their products especially in agricultural and industrial products. In this situation the stakeholders feel that, privatisation may increase the fares for their transportation thereafter it may affect the economy on whole.

\section{Concluding remarks}

The main aim of the study tries to examine the impact of privatisation on Indian railways considering with prospects and consequences approaches. In this aspects, the present study used observational as well as discussion method to extract the information from the stakeholders in their views on privatisation of Indian Railways. The study found that efficiency, quality of services, lesser accidents, fewer political intervene, shareholders value and technological innovation as the prospective measures while adopting privatisation concepts. Further the study reported that limited coverage, higher fares, accountability and impact on economy as the consequences measures while adopting the privatisation. Therefore, these factors must be considered as the important factors while adopting privatisation policy with proper caution. 


\section{Reference}

Astro Talk (2020), "What are the advantages and disadvantages of bringing privatization in railways?", Discussion forum, accessed on 09.06.2020 from Quora site.

Bogart D, and Chaudhary L (2012), "Regulation, Ownership and Costs: A historical perspective from Indian railways", American Economic Journal: Economic Policy, Vol. 4, No. 1, pp. 28-57.

Dalvi M Q (1995), “Should Indian railways be privatised?”, Economic and Political Weekly, Vol. 30, No. 2, pp. 103-112.

Goyal A (2008), "Governance in India's public transport systems: Comparing Indian railways and airlines", Economic and Political Weekly, Vol. 43, No. 28, pp. 119-127.

Gupta N (2002), "Partial privatization and firm performance", Nota di Lavoro, No. 110.2002, Fondazione Eni Enrico Mattei (FEEM), Milano (Working paper series), pp. 1-21.

Hilmola O P, Ujvari S, and Szekely B (2007), "Deregulation of railroads and future development scenarios in Europe: Analysis of the privatisation process taken place in the USA, the UK and Sweden", World Review of Intermodal Transportation Research, Vo. 1, No. 2, pp. 146-169.

Indian Economy (2019), "Privatisation of Indian Railways", Discussion forum, accessed on 09.06.2020 from Dristy site.

Kikeri S, and Nellis J (2004), "An assessment of Privatization", The World Bank Research Observer, Vol. 19, No. 1, pp. 87-118.

Makhija A K (2006), "Privatisation in India”, Economic and Political Weekly, Vol. 41, No. 20, pp. 1947-1951.

Mattoo A (2000), "Indian Railways: Agenda for Reform", Economic and Political Weekly, Vol. 35, No. 10, pp. 771-778.

Pereira V E (2014), "Managing people in the world's largest commercial employer: An exploratory study on Indian railways", Working paper, University of Wollongong, Dubai. 
Towards Excellence: An Indexed, Refereed \& Peer Reviewed Journal of Higher Education / Dr. T.

\title{
Rajasekar \& Dr. Safeer Pasha/ Page 49-59
}

Ponti M, and Erba S (2002), "Railway liberalization from a public choice perspective", Transporti Europei, Vol. VII, No. 20-21, pp. 38-46.

White P, and Ball J (2002), "Experience of national railway privatisation, and of vertical separation in metro system", Transporti Europei, Vol. VII, No. 20-21, pp. 38-46.

\author{
Dr. T. Rajasekar \\ Assistant Professor \\ St. Claret College \\ Bengaluru \\ \& \\ Dr. Safeer Pasha \\ Assistant Professor \\ St. Claret College \\ Bangalore
}

